\title{
On Tropes in English News
}

\author{
Yan Li \\ Department of Foreign Languages \\ The Engineering \& Technical College of Chengdu University of Technology \\ Leshan, Sichuan, China \\ 295199077@qq.com
}

\begin{abstract}
For a piece of English news, in order to draw the readers' attention, the humorous language and the vivid descriptions are especially important parts, and tropes is an important rhetorical device to add to these flavors. This paper illustrates the application of tropes in English news, including simile, metaphor, metonymy and synecdoche, which not only can make one piece of English News more vivid, but also can catch the reader's attention very easily. Besides, the tropes should be used very ingenious and suitable.
\end{abstract}

Keywords-English News, Metaphor, Simile, Metonymy, Synecdoche

\section{INTRODUCTION}

Various news spread all over the world quickly due to the development of science and technology. However, many people wouldn't like to read one whole news paper, for they do not have enough time in their daily life. So the news reporters would try their best to send messages with a few words and simple sentences to attract readers' attention, bearing three questions in their mind: what news is, how to write one piece of perfect news that can catch readers' eyes, and what kind of news readers want to read. And it is noted that taking advantage of tropes is in fact an effective way to catch the readers' attention with humorous and vivid descriptions.

\section{TROPES}

As one of the oldest rhetorical devices, the tropes are often used in English news. It includes simile, metaphor, metonymy, and synecdoche, and so on. Detailed illustrations are as follows:

(a) Simile. This term comes from Latin "similis", which means "like". The definition of simile is "a trope in which one thing is likened to another, in such a way as to clarify and enhance an image" [1]. It is an explicit comparison (as opposed to the metaphor where the comparison is implicit) and usually identified by the markers "like" and "as", as well as "seem", "as if/as though", "compare...to..." and the sentence structure "A is to B what C is to D". Simile can depict something vividly and make a comparison of two different things which have some features in common, linked by the means of the writer's imagination. Simile has tree functions, descriptive, illustrative and illuminative. Descriptive function is for the writer to give a vivid picture about the thing. For example, in the sentence, "The big black flies hit us like bombs", "The big black flies" are compared with "the bombs". It gives a picture of a lot of flies flying together to us. Illustrative function is to explain abstract or complicated ideas or things unfamiliar to you in simple, concrete ideas, or things familiar to you, such as "Tennis is like a Ping-Pong game scaled up to a sizable court" And illuminative function is to give deeper insight into persons or things, such as "Does it stink like a rotten meat?"

(b) Metaphor. Metaphor comes from Latin "metaphor", which means a transfer of a meaning. The definition of metaphor is defined as "it is a trope containing an implied comparison, in which a word or phrase ordinarily and primarily used of one thing is applied to another" [2]. For metaphor, vehicle appears in a quite high frequency and has two forms in a metaphor, visible metaphor, which means the tenor and the vehicle come out at the same time, and invisible metaphor, which means tenor and vehicle don't come out at the same time in one sentence. In English news, metaphor is treated as a compressed or condensed simile. However, metaphor always takes the tenor as the vehicle. So metaphor is stronger, and more powerful than simile. At the same time, the similarities between the tenor and the vehicle are more bright and outstanding than simile.

(c) Metonymy\& Synecdoche. In metonymy, the two things are obviously different, but they are closely associated. However, in synecdoche, there is a kind of association between the whole and the part, the general and the specific or the material and the things made from it. In a short word, metonymy is a trope, which has to do with the substation of the name of one thing for that of another, while synecdoche includes the substation of the part for the whole, the whole for the part, and abstract for specific [3].

Depending on the use of the metonymy in English news, metonymy is mainly used in the following ways: 1) to use a place name, a state name or a specific time for one whole affair, such as "Vietnam" for Vietnam War; 2) to use an organ for its function; 3)to use a name for someone, something or others, such as "Uncle Sam" for America; 4) to use something for its relatives; 5) to use the author for his works, such as "Recently, he was been steeped in O. Henry".

As for synecdoche, it comes from Greek, which is "synecdoche". There are several types in English rhetorical options:

1) A part for the whole, such as "They were short of at harvest time" [4].

2) The whole for the part, such as "Australia beat Canada at cricket" [4]. 
3) Abstract for specific, such as "She was dressed in silks and satins" [4].

About this part, this paper has already explained it.

\section{BASIC KNOWLEDGE OF ENGLISH NEWS}

What is English news? A definition of English news is rather elusive. The answer is easy: a man bites a dog, that's news. In our daily life, a dog bites people, which is a common thing. But if a dog is bit by a man, it would be an earth-shattering thing. This example reveals that a piece of news must be attractive and interesting enough to be reported or something you have never heard before. In the so-called news, "new" is a very important element for a piece of news.

There are many different kinds of news. However, according to the strength of the timeliness and the techniques of news' expression, news basically can be divided into three types: hard news, soft news and the middle layer of news. So, what is hard news? Hard news generally refers to up-to-minute news and events that are reported immediately, which includes the news about politics, war, crime and economics, etc., while soft news is about background information, human-interest stories, with a strong emotion, and witty writing methods. For soft news timeliness is not as important as for hard news. How about the middle layer of news? It is a kind of news between hard news and soft news.

In general, news always pays more attention to timeliness, importance, interest and novelty. So the text must be faithful and smooth, not only to attract readers, but also to help understand what the news wants to express. So to everyone who likes to read news, headline, lead, and the body are often referred to as the three elements of English news, for they play a significant role.

\section{Study On The Tropes In ENGLish News}

As mentioned above, tropes are used in English news and include simile, metaphor, metonymy, and synecdoche, and so on. This section will analyze their applications in English news.

\section{A. Simile in English News}

As one kind of tropes, simile is very simple and common used in news. For readers, if the news writer can use this rhetoric, readers can understand the meaning of this English News easily. What's more, this trope can arouse the readers' interest in a piece of news, and stimulate readers to learn more about the information of this news. For example:

(a) "Libby Defense Portrays Client as a Scapegoat" [5]

The headline is very attractive. In this news, it explores I. Lewis Libby, the vice president's former chief staff, was made a scapegoat by the White House officials to protect the president's longtime political adviser, Karl Rove, which Mr. Libby' s lawyer asserted in his opening statement on Tuesday. "Scapegoat" means a person who is blamed for something bad that somebody else has done or for some failures. For readers, this word is vividly showing that I. Lewis Libby was innocent. In another word, it is very easy to understand what happened or what's going on in America. In this example, the English news writer use simile to help readers understand what this English news wants to express. And to readers, if they want to understand this English news, they must pay more attention to the conjunction, "as". That's to say, "As" is a key word in this sentence. This word can let this piece of news show out in front of readers more vividly.

(b) "The U.S. seems only moderately embarrassed at being 'the biggest piker' in the U.N." [6]

In this sentence, "piker" means a person who is very timid, like a coward. In this English news, Bill Clinton thinks that the U.S. should refuse to pay money to protect their people's safety, for this behavior is like a coward. And the America's allies find that this idea, which is withholding $\$ 1.2$ billion in dues, will force the U.N. to overhaul itself, and becomes very dangerous, even stupid. So the U.S. refuses it. Here, that the writer adopted this rhetorical device is a very smart idea, for he can express the main idea very easily.

\section{B. Metaphor in English News}

As a kind of rhetoric device, metaphor is a significant part of tropes. It is very significant for readers to help them to understand what one piece of difficult news wants to say. There are some examples.

(a) "President Bush strolls into fortress Britain" [7]

From this English News, the writer wants to explore that President Bush arrived in London with a lot of noise. Faced with British and European anti-war people, Bush must be careful with arrangements with a lot of security measures. "Fortress Britain" simply summarized careful deployment of Bush's trip in the U.K. In this piece of English news, there isn't any symbolic conjunction of tropes. That is to say, metaphor is different from simile. Metaphor doesn't have a symbolic words or a marker in this sentence. However, metaphor also has its own features. Just like this piece of English news, the news writer used one word, "fortress", to express that it is a dangerous thing for President Bush in U.K. He should be protected by many armed men.

(b) 'Citizen Science Takes Off'. [8]

In this News, the reporter wants to tell us that members of one community's labs want to display the science's benefits to others who don't pay attention to science. "Take off" means something becomes successful or popular very quickly and suddenly. This phrase vividly shows the power of science in community labs. In this piece of English news, the writer compares the process of lab's member learning science to the science tour. It is very simple to understand for readers. At the same time, metaphor makes this sentence very compact and simple. It doesn't need other exaggerating words to modify it.

(c) "Path of the Storm" [9]

The news explains the super lobbyist, Abramoff, sets off the republican scandal in America in 2005. The news writer compares the republican scandal to a storm, revealing the harmful effect of that event vividly. This headline is very simple and short, but it is very powerful for readers who can feel a very furious debate through the four words. Metaphor, as one of tropes, can express one thing simply and vividly. 


\section{Metonymy and Synecdoche in English News}

Metonymy and synecdoche are often used in English news. In this way, the news' characteristics are more distinct. What's more, the language of English news is more expressive, and the readers are able to appreciate the appeal of English news.

There are some examples to help readers to know about it.

(a) "So many big countries like to control other small countries-with a brilliant ear and an iron fist" [10]

Metonymy is applied in this news. We can find two organs on behalf of their functions. The first one is "ear", which means sense of hearing. The second one is "iron fist", which means doing something's attitude, in Chinese "Shoo Wan". In this way, it can not only help readers to understand this news, but also let this news simple and symbolic. In other words, this kind of rhetoric device can make an interesting article.

(b) "The pen is mightier than the sword" [11]

In this piece of English news, metonymy is applied. The writer wants to express that he admires the scholar more than the man of prowess. Writers just use the simple word to express his feeling.

(c) "The car knocked out" [12]

In this sentence, "the car" represents the engine, one type of synecdoche, the whole for the part. For readers, engine is more abstract than car. Car is a specific concept, and more common than engine in our daily life. So in this piece of English News, "car" is easier than "engine" to understand for readers.

\section{CONCLUSION}

In English news, rhetorical devices can make one piece of news more lively and vivid. The tropes are significant for one piece of news. Simile and metaphor are commonly used in English news. These two can help readers to understand some hidden information easily in some articles, for the descriptions with the two rhetoric devices are so vivid. Metonymy and synecdoche can also make one piece of news more vivid and simple for readers. In conclusion, these rhetorical devices can increase the article's readability and make English news more attractive.

\section{REFERENCES}

[1] John A. Cuddon, A Dictionary of Literary Terms. Michigan University: Doubleday Company press, 1977

[2] Michael E. Agnes, The Webster's New World Dictionary. Liaoning: Simon \& Schuster Press, 2003.

[3] B. Philip Gove, The Webster's Third New International Dictionary. K.nemannim Tandem Press, 1993.

[4] Feng Cuihua, English Rhetorical Options. Beijing: Foreign language teaching and research press, 2004, pp. 199-201.

[5] A. Neil Lewis, "Libby Defense Portrays Client as a Scapegoat." The New York Times, January 24, 2007.

[6] Carol Bogert, "Midlife Crisis," Newsweek, October 30, 1995.

[7] Daniel Gross, "The Economy Sucks. But Is It '92 Redux?" The Thames, November 23, 2003.

[8] Adrienne Burke, "Citizen Science takes off." October 25, 2011. www.forbes.com/sites/techonomy/2011/10/25/citizen-science-takes -off-could-community-labs-hatch-the-next-generation-of-bio-innova tors/ (accessed May 27, 2014)

[9] Richard Wolff and Holly Bailey, "Path of the Storm." Newsweek, April 17, 2006

[10] Richard Willing and Jim Drinkard, “ U.S. under Attack," USA Today, September 11, 2001.

[11] Kim, Lim. "Cooperation between Chinese Media and Media from ASEAN Way Forward.” August 26, 2004.

http://www.people.com.cn/BIG5/guoji/8212/36645/36653/2741820. htm/ (accessed May 27, 2014)

[12] S. Stephen Roach, "Rebalancing of the economy." China Daily, March 3, 2014 